\title{
Reproductive Health Information and Practice among Female Undergraduates of Private Universities in Osun State, Nigeria
}

\author{
Alarape, A. A. ${ }^{1}$ Ogunniran, O. O. ${ }^{2} \quad$ Omoba, F. A. ${ }^{3}$ \\ 1.Department of Educational Technology and Library Studies, Obafemi Awolowo University, Ile-Ife Osun State \\ Nigeria \\ 2.Directorate of General Education Studies, Adeleke University, Ede Osun State, Nigeria \\ 3.Hezekiah Oluwasanmi Library, Obafemi Awolowo University, Ile-Ife, Osun State Nigeria
}

\begin{abstract}
The research investigated the extent of awareness of reproductive health information and practice of female undergraduate in private universities in Osun State. The study employed the descriptive survey research design. The population for the study consisted of all the female undergraduates of private universities in Osun state. A total of 500 female undergraduates of private universities in Osun state formed the sample for this study. Proportionate sampling technique was used to assigned sample size to each of the three randomly selected universities to ensure fair representation. Simple random sampling technique was employed to select sampled size assigned to each of the selected universities. The instrument used to collect data was questionnaire titled "awareness of reproductive health information and reproductive health practice (APRHIQ). Data collected were analysed using frequency count, mean and standard deviation. The findings showed that young people are sexually active as majority have started engaging in sexual activities while still in secondary schools. The findings also indicated that awareness of reproductive health information is of a very low extent $(45.6 \%)$ and reproductive health practice of female undergraduate is of a high extent $(54.4 \%)$. The study concluded that Reproductive Health Information awareness is very low while reproductive health practice of female undergraduate of private universities in Osun state tends to be favourable. The study recommended that in order to avert the imminent threat of explosion of sexually transmitted diseases, there is urgent need to start teaching family life and sex education in schools right from elementary school.
\end{abstract}

Keywords: Information Awareness; Reproductive Health Information; Undergraduate, Reproductive Health Practice

DOI: $10.7176 / \mathrm{JEP} / 12-16-09$

Publication date:June $30^{\text {th }} 2021$

\section{Introduction}

Reproductive health (RH) education, a basic right for women, enriches their knowledge and awareness, providing them with the tools to understand their responsibilities and rights (WHO, 2008). Proper (RH) promotion is scarce in many countries, and particularly in developing countries. The disparity between international trends in $\mathrm{RH}$ and the state of affairs in these countries is linked to a shortage of skilled health services and lack of appropriate health services, the shortage of teachers able and willing to communicate about sensitive matter, and religious and cultural taboos (United Nation Educational, Scientific and Cultural Organization, 2018). All of these factors may contribute to a diminution in women's self-confidence and ability to make informed RH choices. There is limited discussion of issues concerning reproductive health in general and sexual education in particular, in countries in the Middle East and Africa (Hall et al., 2012). They went further to say that, absence of knowledge means women are not in a position to make informed and correct RH decision or choices. This brings about the consequence for women to likely suffer from sexually transmitted infections and unwanted pregnancies, particularly the unmarried ones which can be extremely damaging socially. In Saudi Arabia, women's RH is an area which is usually linked with morality and tradition. It is often presented as an aspect of religion and always connected to Islamic teaching in such community.

\section{Information Awareness (IA)}

Reproductive health awareness is an educational approach which is both relevant and sensitive to enrich women of knowledge and ability. It also provides them with the tools to understand their responsibilities, rights reproductive health needs and concerns. It is a simple non-threatening way for programs to quickly expand beyond pure information giving and explore what reproductive health means to people. Although many communities sexual and reproductive health programs do not include the term reproductive health awareness, but techniques similar to the reproductive health awareness education approach are being used during discussions. If reproductive health awareness is identified and included as one of the dimensions of future sexual and reproductive health programs, this will hopefully strengthen the program's overall quality and effectiveness. Female's reproductive health has attracted many large-scale public health initiatives like Healthy People, UN Millennium Project, because, it is considered both an indicator of population health and a benchmark of progress 
in a society. Nigeria has consistently been reported as having one of the highest rates of population growth in the world and faces significant reproductive health issues including high maternal mortality, endemic HIV/AIDS, unwanted pregnancy and high levels of sexually transmitted infections. Majority of the contemporary young people across the globe are engaged into alarming proportions of sexual activity, yet ill-prepared to protect themselves from the attendant risks. More significantly, research has shown that sexually active young people especially in Nigerian universities like other young people are seriously engaged in the practice of unprotected sex mainly due to negative attitude they hold about the existing family planning methods (Bloom 2011; UNAIDS 2010 \& WHO 2001).

Adebusonye (1999) conducted a research among 2,769 in-school young female and 2,803 male adolescents in Ibadan, South-West of Nigeria, having a high proportion of the subjects with current boy/girlfriends. When asked whether they are interested in future family planning, only a very low proportion, $18 \%$ of the total females sampled responded in the affirmative while $68 \%$ of the females gave just any reason for not wanting to accept the program. Even when asked pertaining to the choice of procedure into marriage in terms of how many children they will have, the study showed that as many as $69 \%$ gave a non-numeric answer "God provides". The low proportion among this urban young population who indicated interest in future family planning points to the fact that such attitude to family planning in future may not exert the desired effect on future risk reduction. This kind of finding can be an indication of the increased sexually transmitted infections (STIs), unwanted pregnancy, illegally induced abortion, unintended pregnancy, child abandonment among other reproductive health ills in our communities.

\section{Reproductive Health information (RHI)}

Furthermore, when it comes to the reproductive health practice, the youths become point of concern in that, this is the age when most of them experience a ludicrous sense of lust which they mostly term love. More than half the world's youth are initiating their sexual activity during their adolescence years according to UNAIDS, (2004). Every year, half of new HIV infected cases and one-third of the 340 million new STIs occur in people ages 1- 25 years. Each year, more than 1 in 20 adolescents contracts a curable STI. Every minute, 10 female adolescents around the world undergo unsafe abortion (Population Action International, 2002). In spite of the fact that religious teaching and cultural norms in Nigeria emphasized abstinence from sexual activity until permanent marriage, in reality sexual activity before and outside marriage occurs in every society. The few studies of the knowledge, attitude, beliefs and behaviours about sexual reproductive health of Nigerian youth have demonstrated poor knowledge about reproductive health. Ajuwon (2005) in their study of the effect of educational intervention on reproductive health knowledge, attitude and practice among secondary school students in Oyo State, confirmed that some young people believed that pregnancy cannot occur during the first sexual episode, whereas others believe that such methods as rhythm method and abstinence are not only difficult to use but not reliable, and that the use of other methods will conflict with their health.

In the same vein, Oyo-Ita, et al (2002) researched on knowledge of reproductive health issues among secondary school adolescents in Calabar and found that among the sexually active young people, $50 \%$ of 166 respondents believed that taking a few capsules of antibiotics soon after sex will prevent any risk. Otoide, et al (2001) in a study of 149 respondents aged 15-19 in Benin City, Nigeria noted that $86 \%$ prefer abortion, stating that the use of family planning methods is riskier than abortion irrespective of the fact that it is the leading cause of maternal mortality in Nigeria with $80 \%$ of the death occurring among young people. To this end, World Health Organization (WHO, 2001) lamented that such attitude towards preventive measures points to the fact that young people are not either properly taught or lack sufficient details about sex and it related issues. Further to this, Adamchak, et al (2001) contended that when young people possess adequate knowledge about sexual risks and preventive measures, their sexual behaviour may tend to be responsible involving preventive attitude.

\section{Reproductive Health Practice (RHP)}

Inadequate awareness of reproductive health information as well as ill reproductive health practice of female undergraduate, sexual risks, preventive measures and their sexual attitude potentially may put this significant group of the population into devastating reproductive health risks. This health risks include early unintended pregnancy and sexually transmitted infections (STIs) among many others. The consequences of these risks could be more disastrous for the young undergraduate students, who if they become victims run the risks of dropping out of school. Family planning services which place emphasis on the birth control/communication program and contraceptive technology is an important aspect of ensuring sexual and reproductive health education. This information therefore, helped in achieving the millennium development goals aimed at striking a marked improvement in the overall health status of citizens in 2015 (WHO, 2015). As young people engage in early sexual activity, one would have thought that they will be ready to take responsibility for their own actions. Negligence attitude among this vulnerable group has reportedly led to the falling standard of their reproductive health and therefore needs urgent attention. Moreover, most of the studies on family planning issues bordered on 
negative attitude among adults, young adults, married and unmarried alike.

According to the global observatory data of the World Health Organization (WHO, 2015), about 830 women were said to have died daily in 2015 as a result of complications of pregnancy and child birth, most of which could have been averted if earlier reported. It is believed that most of the reproductive health issues observed during the productive age $(12-49$ years $)$ could have been nipped in the bud if disclosed to the health practitioners/experts at the early stage. Majority of the contemporary young people across the globe are engaged in alarming proportions of sexual activity, yet ill-prepared to protect themselves from the attendant risks. More significantly, research has shown that sexually active young people especially in Nigerian universities like other young people are seriously engaged in the practice of unprotected sex mainly due to negative attitude they hold about the existing family planning methods. This attitude is unhealthy for this significant group of the population as it exposes them to series of devastating reproductive health risks of early pregnancy/unwanted pregnancy and sexually transmitted infections (STIs).

The multiplier effects will be on the culprits, immediate family and the society. Over the years, in every Nigerian community, high premium is placed on virtuous living and sexual relationship is considered as a sacred exercise reserved for adult and mature male and female. Irrespective of individual religious beliefs, the culture value and respect for sexual activity is upheld to the extent of being considered an abomination doing it during the broad day light. Adults do not discuss sexuality with the young persons with the fear that they might be exposed to immorality. The invasion of technology and civilization has however made the act as well as the information on it readily available. The technology has however encouraged and enables youth access to western cultures where those counted as abominations are norms and order of the day. These adolescents strive to experiment what they learnt from these sources without adequate knowledge on how to protect themselves. It is against this backdrop, that this study investigated the awareness and practice of reproductive health education among female undergraduates of private universities in Osun State, Nigeria.

\section{Purpose of the Study}

The general aim of this study is to investigate awareness and practice of reproductive health information among female undergraduates of private universities in Osun state.

Specifically, the study:

i. Identified the extent of awareness of reproductive health information among female undergraduates of private universities in Osun state,

ii. Determined the extent of reproductive health practice among female undergraduates of private universities in Osun state.

\section{Research Questions}

i. What is the extent of awareness of reproductive health information among female undergraduates of private universities in Osun state?

ii. What is the extent of reproductive health practice among female undergraduates of private universities in Osun state?

\section{Methodology}

The research adopted a descriptive survey research design. The target population of the study focused on female undergraduates of whom 100 and 200 levels were purposively chosen as this is the group that has just completed their secondary school education and proceeded to their tertiary education level. There are seven private universities in the state out of which simple random technique was used to select three universities namely: Redeemer's University, Ede - 2,012, Bowen University, Iwo-2,104 and Joseph Ayo Babalola University, IkejiArakeji, 1,540 female undergraduate respectively. The sample size for the study is 500 the number selected with the use of multi stage sampling procedure. At first, three out of the seven private universities were selected using simple random technique. Thereafter, proportionate sampling technique was used to allocate sample to the selected universities thus: Redeemer's University, Ede. 177; Bowen University, Iwo, 183; and Joseph Ayo Babalola University, Ikeji-Arakeji, 88. The selection from each of the selected universities were done using simple random technique. A set of questionnaires titled "Awareness and Practice of Reproductive Health Information Questionnaire (APRHIQ) was employed to obtain data from the respondents. Data collected were analysed with the use of descriptive statistics.

\section{Findings and Discussion}

8.1 Research Question One: What is the extent of awareness of reproductive health information of female undergraduates of private universities in Osun state? 
Table 1. Extent of awareness of reproductive health information among female undergraduates

\begin{tabular}{|c|c|c|c|c|c|c|c|}
\hline \multicolumn{2}{|r|}{ Health } & \multirow[t]{2}{*}{ Responses } & \multirow{2}{*}{$\begin{array}{l}\text { High } \\
\text { Extent }\end{array}$} & \multicolumn{2}{|c|}{ Moderate Low } & \multirow{2}{*}{$\begin{array}{c}\text { No } \\
\text { Xxtent }\end{array}$} & \multirow[t]{2}{*}{ Mean } \\
\hline & Issues & & & Extent & Extent & & \\
\hline \multirow[t]{2}{*}{1} & \multirow[t]{2}{*}{$\begin{array}{l}\text { Have you ever engaged } \\
\text { in sexual activities }\end{array}$} & During the Last 3 Months & $108(21.6)$ & $\begin{array}{l}100 \\
(20.0)\end{array}$ & $\begin{array}{l}100 \\
(20.0)\end{array}$ & $\begin{array}{l}192 \\
(38.4)\end{array}$ & 2.3 \\
\hline & & Before the Last 3 Months & $111(22.2)$ & $110(22.0)$ & $159(31.8)$ & $120(24.0)$ & 2.4 \\
\hline \multirow{2}{*}{\multicolumn{2}{|c|}{$\begin{array}{l}2 \text { Faced sexual and } \\
\text { reproductive health } \\
\text { problems due to sexual } \\
\text { activities }\end{array}$}} & & & & & & 1.9 \\
\hline & & During the Last 3 Months & $70(14.0)$ & $97(19.4)$ & $100(20.0)$ & $233(46.6)$ & \\
\hline \multirow[t]{4}{*}{4} & \multirow{4}{*}{$\begin{array}{l}\text { What is your extent of } \\
\text { awareness of these } \\
\text { basic conditions for } \\
\text { pregnancy? }\end{array}$} & f Sex & $190(38.8)$ & $304(60.8)$ & $06(1,2)$ & - & 3.4 \\
\hline & & Sperm & $189(37.8)$ & $300(60.0)$ & $11(2.2)$ & - & 3.4 \\
\hline & & Genital tract & $100(20.0)$ & $186(37.2)$ & $116(42.8)$ & $100(20.0)$ & 2.6 \\
\hline & & Uterus & $103(20.6)$ & $122(24.4)$ & $44(8.8)$ & $121(24.2)$ & 1.9 \\
\hline 5 & $\begin{array}{l}\text { How informed are you } \\
\text { that Ovulation happens } \\
\text { on the } 14 \text { th day before } \\
\text { next menstruation }\end{array}$ & $\begin{array}{l}\text { Ovulation happens on the } 14 \text { th } \\
\text { day before next menstruation }\end{array}$ & $197(39.4)$ & $95(19.0)$ & $96(19.2)$ & $112(22.4)$ & 2.8 \\
\hline & $\begin{array}{l}6 \text { Do you think it is } \\
\text { necessary to have the } \\
\text { contraceptive } \\
\text { knowledge? }\end{array}$ & $\begin{array}{l}\text { contraceptive knowledge is } \\
\text { necessary }\end{array}$ & $131(26.2)$ & $185(37.0)$ & $102(20.4)$ & $82(16.4)$ & 2.7 \\
\hline & \multirow{3}{*}{$\begin{array}{l}\text { Who should } \\
\text { response } \\
\text { contraception? }\end{array}$} & Man & $104(20.8)$ & $220(44.0)$ & $176(35.2)$ & - & 2.9 \\
\hline & & Woman & $103(10.6)$ & 193(38.6) & $204(40.8)$ & - & 2.8 \\
\hline & & $\begin{array}{l}\text { Both of them } \\
\text { responsibility }\end{array}$ & $176(35.2)$ & $296(59.2)$ & $28(5.6)$ & - & 3.3 \\
\hline \multirow{11}{*}{\multicolumn{2}{|c|}{$\begin{array}{l}8 \text { What is the extent of } \\
\text { awareness of the } \\
\text { following methods of } \\
\text { preventing pregnancy? }\end{array}$}} & f Condom & $287(57.4)$ & $200(40.0)$ & $13(2.6)$ & - & 3.5 \\
\hline & & Mensural Diary & $55(11.0)$ & $150(30.0)$ & $205(41.0)$ & $90(18.0)$ & 2.3 \\
\hline & & Injectable & $53(10.6)$ & $106(21.2)$ & $171(34.2)$ & $170(34.0)$ & 2.1 \\
\hline & & Vasectomy & $92(18.3)$ & $102(20.5)$ & $150(61.2)$ & $156(31.2)$ & 2.3 \\
\hline & & Tubectomy & $44(8.8)$ & $175(35.0)$ & $81(16.2)$ & $200(40.0)$ & 2.1 \\
\hline & & Withdrawal & $16(3.2)$ & $84(16.8)$ & $189(37.8)$ & $211(42.2)$ & 1.8 \\
\hline & & Douche & $80(16.0)$ & $127(25.4)$ & $63(12.6)$ & $230(46.0)$ & 2.3 \\
\hline & & Spermicide & $24(4.8)$ & $43(8.6)$ & $58(11.6)$ & $375(75.0)$ & 1.6 \\
\hline & & Vaginal Diaphragm & $22(4.4)$ & $53(10.6)$ & $100(20.0)$ & $325(65.0)$ & 1.5 \\
\hline & & Norplant & $50(10.0)$ & $149(29.8)$ & $51(10.2)$ & $250(50.0)$ & 1.9 \\
\hline & & IUD & $08(1.6)$ & $60(12.0)$ & $77(13.4)$ & $355(71.0)$ & 1.4 \\
\hline \multirow{12}{*}{\multicolumn{2}{|c|}{. }} & Pregnancy test & $40(8.0)$ & $127(25.4)$ & $198(66.6)$ & $135(27.0)$ & 2.1 \\
\hline & & Mass-media messages & $25(5.0)$ & $95(19.0)$ & $195(39.0)$ & $185(37.0)$ & 2.1 \\
\hline & & STD screening & $21(4.2)$ & $100(20.0)$ & $90(18.0)$ & $289(57.8)$ & 1.7 \\
\hline & & Illness of close friend due to STI & $13(2.6)$ & $26(5.2)$ & $181(36.2)$ & $280(56.0)$ & 1.5 \\
\hline & & $\begin{array}{l}\text { Death of close relative due to STI } \\
\text { abortion }\end{array}$ & $\mathrm{o} 02(0.4)$ & $07(1.4)$ & $96(19.2)$ & $395(79.0)$ & 1.2 \\
\hline & & Others (counselling service) & $14(2.8)$ & $13(2.6)$ & $141(28.2)$ & $332(66.4)$ & 1.4 \\
\hline & & Virtual social media & $91(18.2)$ & $205(41.0)$ & $164(32.8)$ & $40(8.0)$ & 2.7 \\
\hline & & Family planning advocacy/Clinic & $99(19.8)$ & $106(21.2)$ & $20(4.0)$ & $275(55.0)$ & 2.1 \\
\hline & & $\begin{array}{l}\text { Family members/ Parents, sister } \\
\text { and brothers }\end{array}$ & r:71(14.2) & 103(20.6) & $126(25.2)$ & $200(40.0)$ & 2.1 \\
\hline & & Workshops/Seminar and meetings & $44(8.8)$ & $132(26.4)$ & $100(20.0)$ & $224(44.8)$ & 1.9 \\
\hline & & Peer Group/Friends/ Classmates & $143(28.6)$ & $255(51.0)$ & $81(16.2)$ & $21(4.2)$ & 3.0 \\
\hline & & Library & $34(6.8)$ & $123(24.6)$ & $120(24.0)$ & $223(44.6)$ & 1.96 \\
\hline
\end{tabular}

Note: 0.0-1.4 = No Extent, 1.5- 2.4 = Low Extent, 2.5- $3.4=$ Moderate Extent, 3.5- 4.00 = High Extent

On the extent of awareness of reproductive health information among female undergraduates of private's universities in Osun state, table 1 presented the extent of awareness of basic conditions for pregnancy as having 
sex $($ mean=3.4) and sperm $($ mean=3.4) which indicated that the students are aware of what make up a pregnancy; methods of preventing pregnancy (condom -mean=3.5) showed that the female undergraduates have high extent of awareness on how to prevent pregnancy using condom. Also, there is moderate awareness on who should be responsible for contraception with man and woman having a mean of 3.3. This implied that the students have an idea of whose responsibility it is to procure contraceptive in any form. The undergraduates also indicated that to a moderate extent, they have their sources of awareness of health reproductive information from peer group, friends and classmates (mean=3.0).

On the other hand, the table revealed that among the female undergraduates, there is a low extent of their engagement in sexual activities in the last three months (mean=2.4) before carrying out this research. Some of the students also agreed that to a very low extent, they are not aware of Injectable (mean=2.1); Tubectomy (mean=2.1); Withdrawal (mean=2.1); Spermicide (mean=1.6); Vaginal Diaphragm (mean=1.5); IUD $($ mean=1.4) as means of preventing pregnancy. Furthermore, some of the students indicated of not being aware of sources of STD screening (mean=1.7) or death of close relative due to STI or abortion (mean=1.2). Also, sources of awareness such as counselling services $($ mean $=1.4)$ and workshops/ seminar and meetings $($ mean $=1.9)$ were either at no extent or low extent of awareness by the students.

The weighted mean of the table is given as 2.2 , an indication that awareness of reproductive health information is to a moderate extent among the female undergraduates. The result of this study agreed with the earlier works of Adamchak, et al (2000) which emphasized that when young people possess adequate knowledge about sexual risks and preventive measures, their sexual behaviour may tend to be responsible involving preventive attitude. This study also supported the work of Adebusonye (1999) in Ibadan, South West of Nigeria noted that among 2,769 and 2,803 in-school young female and male adolescents respectively a high proportion of the subjects had current boy/girlfriends.

8.2 Research Question Two: What is the extent of reproductive health practice among female undergraduates of private universities in Osun state?

Table 2: Extent of reproductive health practice among female undergraduates

\begin{tabular}{|c|c|c|c|c|c|c|c|c|}
\hline $\mathbf{S} / \mathbf{N}$ & $\begin{array}{l}\text { Reproductive } \\
\text { Health Practice }\end{array}$ & Variables & $\begin{array}{l}\text { High } \\
\text { Extent }\end{array}$ & $\begin{array}{l}\text { Moderat } \\
\text { e } \\
\text { Extent } \\
\end{array}$ & $\begin{array}{l}\text { Low } \\
\text { Extent }\end{array}$ & $\begin{array}{l}\text { Never/ } \\
\text { No } \\
\text { Extent }\end{array}$ & Mean & SD \\
\hline 1 & $\begin{array}{l}\text { To what extent } \\
\text { have you engaged } \\
\text { in } \\
\text { activities? }\end{array}$ & $\begin{array}{l}\text { I have engaged in } \\
\text { sexual activities to } \\
\text { some.... }\end{array}$ & \multicolumn{2}{|c|}{$190(38.0) 102(20.4)$} & $90(18.0)$ & $118(23.6)$ & 2.7 & 1.03 \\
\hline 2 & $\begin{array}{l}\text { Do you agree to } \\
\text { the fact that sexual } \\
\text { activities are not } \\
\text { the function of age } \\
\text { but exposure? }\end{array}$ & $\begin{array}{l}\text { Sexual activities are } \\
\text { not the function of } \\
\text { age but exposure }\end{array}$ & \multicolumn{2}{|c|}{ 106(21.2)102(20.4) } & $22(5.4)$ & $270(54.0)$ & 2.1 & 0.90 \\
\hline 3 & $\begin{array}{l}\text { I face sexual and } \\
\text { reproductive } \\
\text { health problems } \\
\text { due to my sexual } \\
\text { activities }\end{array}$ & $\begin{array}{l}\text { Extent of facing } \\
\text { sexual and } \\
\text { reproductive health } \\
\text { problem }\end{array}$ & $70(14.0)$ & $97(19.4)$ & $63(12.6)$ & $270(54.0)$ & 1.9 & 0.91 \\
\hline 4 & $\begin{array}{l}\text { Sexual activities } \\
\text { are pleasurable for } \\
\text { me all the time }\end{array}$ & $\begin{array}{l}\text { Feelings of pleasure } \\
\text { for sexual activities }\end{array}$ & $50(10.0)$ & $180(36.0)$ & $172(34.4)$ & $98(19.6)$ & 2.4 & 1.02 \\
\hline \multirow[t]{3}{*}{5} & $\begin{array}{l}\text { What is your take } \\
\text { on these basic }\end{array}$ & Sperm & $24(4.8)$ & $400(80.0)$ & $43(8.6)$ & $33(6.6)$ & 2.8 & 1.01 \\
\hline & conditions for & Genital tract & $22(4.4)$ & $53(10.6)$ & $300(60.0)$ & $125(25.0)$ & 1.9 & 0.97 \\
\hline & $\begin{array}{l}\text { pregnancy? } \\
\text { (Multiple choice) }\end{array}$ & Uterus & $50(10.0)$ & $149(29.8)$ & $200(40.0)$ & $101(20.2)$ & 2.3 & 0.93 \\
\hline \multirow[t]{2}{*}{6} & $\begin{array}{l}\text { To what extent do } \\
\text { you agree with the } \\
\text { relationship }\end{array}$ & $\begin{array}{l}\text { After ovulation will } \\
\text { have } \\
\text { menstruation }\end{array}$ & $08(1.6)$ & $60(12.0)$ & $230(46.0)$ & $202(40.4)$ & 1.8 & 1.04 \\
\hline & $\begin{array}{l}\text { between Ovulation } \\
\text { and menstruation } \\
\text { periods }\end{array}$ & $\begin{array}{l}\text { The temperature is } \\
\text { rising in menstrual } \\
\text { period }\end{array}$ & $40(8.0)$ & $127(25.4)$ & $190(38.0)$ & $143(28.6)$ & 2.1 & 0.93 \\
\hline
\end{tabular}




\begin{tabular}{|c|c|c|c|c|c|c|c|c|}
\hline $\mathbf{S} / \mathbf{N}$ & $\begin{array}{l}\text { Reproductive } \\
\text { Health Practice }\end{array}$ & Variables & $\begin{array}{l}\text { High } \\
\text { Extent }\end{array}$ & $\begin{array}{l}\text { Moderat } \\
\text { e } \\
\text { Extent }\end{array}$ & $\begin{array}{l}\text { Low } \\
\text { Extent }\end{array}$ & $\begin{array}{l}\text { Never/ } \\
\text { No } \\
\text { Extent }\end{array}$ & Mean & SD \\
\hline & & $\begin{array}{l}\text { Ovulation } \begin{array}{r}\text { happens } \\
\text { on the 14th day } \\
\text { before } \\
\text { menstruation }\end{array} \\
\end{array}$ & $25(5.0)$ & $95(19.0)$ & $200(40.0)$ & $180(36.0)$ & 2.1 & 1.17 \\
\hline & & $\begin{array}{l}\text { Ovulation happens } \\
\text { on the 14th day } \\
\text { behind menstruation }\end{array}$ & $21(4.2)$ & $100(20.0)$ & $209(41.8)$ & $170(34.0$ & 1.9 & 1.03 \\
\hline 7 & $\begin{array}{l}\text { The knowledge of } \\
\text { contraceptives is } \\
\text { important for its } \\
\text { choice and } \\
\text { effective usage }\end{array}$ & $\begin{array}{l}\text { knowledge } \\
\text { contraceptives }\end{array}$ & $24(4.8)$ & $43(8.6)$ & $203(40.6)$ & $230(46.0)$ & 1.7 & 1.03 \\
\hline 8 & $\begin{array}{l}\text { I prefer using } \\
\text { contraceptive } \\
\text { during sexual } \\
\text { intercourse? }\end{array}$ & Use contraceptives & $22(4.4)$ & $53(10.6)$ & $205(41.0)$ & $220(44.0)$ & 1.8 & 0.90 \\
\hline \multirow[t]{3}{*}{9} & Which of the & Man & \multicolumn{2}{|c|}{$104(20.8) 220(44.0)$} & $150(30.0)$ & $26(5.2)$ & 2.8 & 0.91 \\
\hline & following people & Woman & \multicolumn{2}{|c|}{ 103(10.6)193(38.6) } & $103(20.6)$ & $101(10.2)$ & 2.6 & 1.02 \\
\hline & $\begin{array}{l}\text { should be } \\
\text { responsible for } \\
\text { contraceptives? }\end{array}$ & $\begin{array}{l}\text { Both of them have } \\
\text { responsibility }\end{array}$ & \multicolumn{2}{|c|}{$176(15.2) 206(41.2)$} & $28(5.6)$ & $90(18.0)$ & 2.9 & 1.01 \\
\hline \multirow[t]{9}{*}{10} & $\begin{array}{l}\text { To what extent do } \\
\text { you think the }\end{array}$ & $\begin{array}{l}\text { Contraceptive } \\
\text { effectiveness }\end{array}$ & \multicolumn{2}{|c|}{$200(40.0) 127(25.4)$} & $40(8.0)$ & $133(26.6)$ & 2.8 & 0.97 \\
\hline & $\begin{array}{l}\text { following factors } \\
\text { influence the } \\
\text { consideration for }\end{array}$ & $\begin{array}{l}\text { The feeling of using } \\
\text { contraceptive } \\
\text { methods }\end{array}$ & $25(5.0)$ & $95(19.0)$ & $43(8.6)$ & $337(67.4)$ & 1.6 & 0.93 \\
\hline & $\begin{array}{l}\text { choice of } \\
\text { contraceptive } \\
\text { methods }\end{array}$ & $\begin{array}{l}\text { The convenience of } \\
\text { buying or using } \\
\text { contraceptive tool }\end{array}$ & $79(17.8)$ & $57(11.4)$ & $21(4.2)$ & $443(88.6)$ & 1.9 & 1.04 \\
\hline & & $\begin{array}{l}\text { The safety of } \\
\text { contraceptive method }\end{array}$ & $53(10.6)$ & $66(12.2)$ & $100(20.0)$ & $281(56.2)$ & 1.7 & 0.93 \\
\hline & & Affecting fertility & $24(4.8)$ & $43(8.6)$ & $230(46.0)$ & 203(40.6) & 1.8 & 1.17 \\
\hline & & $\begin{array}{l}\text { Affecting the } \\
\text { regularity of the } \\
\text { menstrual cycle }\end{array}$ & $55(11.0)$ & $53(10.6)$ & $22(4.4)$ & $370(74.8)$ & 1.6 & 1.03 \\
\hline & & Risk of weight gain & $60(12.0)$ & $9(8.8)$ & $50(10.0)$ & $341(68.2)$ & 1.5 & 0.90 \\
\hline & & Nausea/vomit & $24(4.8)$ & $(8.6)$ & $203(40.6)$ & $230(46.0)$ & 1.5 & 0.91 \\
\hline & & No side effect & $50(10.0)$ & $2(4.4)$ & $53(10.6)$ & $375(75.0)$ & 1.5 & 1.03 \\
\hline 12 & $\begin{array}{l}\text { Have you ever had } \\
\text { unintended } \\
\text { pregnancy }\end{array}$ & $\begin{array}{l}\text { Have you ever had } \\
\text { unwanted pregnancy }\end{array}$ & $70(14.0)$ & (19.4) & $33(6.6)$ & $303(60.6)$ & 1.3 & 0.90 \\
\hline \multirow[t]{3}{*}{13} & \multirow{3}{*}{$\begin{array}{l}\text { Which of the } \\
\text { following method } \\
\text { do you think is } \\
\text { saver in dealing } \\
\text { with unintended } \\
\text { pregnancy }\end{array}$} & Surgical & $87(17.4)$ & $3(12.6)$ & $150(30.0)$ & $200(40.0)$ & 1.7 & 0.91 \\
\hline & & Medical abortion & $91(18.2)$ & $5(41.0)$ & $54(10.8)$ & $250(50.0)$ & 1.5 & 1.02 \\
\hline & & $\begin{array}{l}\text { Preparing to give } \\
\text { birth to the child }\end{array}$ & $99(19.8)$ & $6(21.2)$ & $05(21.0)$ & $290(58.0)$ & 1.8 & 1.01 \\
\hline \multirow[t]{4}{*}{14} & \multirow{4}{*}{$\begin{array}{l}\text { How does the } \\
\text { following impact } \\
\text { your sexual and } \\
\text { contraceptive } \\
\text { knowledge }\end{array}$} & Pregnancy test & $25(5.0)$ & $95(19.0)$ & $85(17.0)$ & $295(59.0)$ & 1.1 & 0.97 \\
\hline & & $\begin{array}{l}\text { Mass-media } \\
\text { messages }\end{array}$ & $79(75.8)$ & $100(20.0)$ & $21(4.2)$ & $379(35.8)$ & 1.5 & 0.93 \\
\hline & & STD screening & $13(2.6)$ & $67(5.2)$ & $100(92.2)$ & $300(60.0)$ & 1.5 & 1.04 \\
\hline & & $\begin{array}{l}\text { Illness of close friend } \\
\text { due to STI }\end{array}$ & $24(4.8)$ & $43(8.6)$ & $90(86.6)$ & $343(68.6)$ & 1.5 & 0.93 \\
\hline
\end{tabular}




\begin{tabular}{|c|c|c|c|c|c|c|c|c|}
\hline $\mathbf{S} / \mathbf{N}$ & $\begin{array}{l}\text { Reproductive } \\
\text { Health Practice }\end{array}$ & Variables & $\begin{array}{l}\text { High } \\
\text { Extent }\end{array}$ & $\begin{array}{l}\text { Moderat } \\
\text { e } \\
\text { Extent } \\
\end{array}$ & $\begin{array}{l}\text { Low } \\
\text { Extent }\end{array}$ & $\begin{array}{l}\text { Never/ } \\
\text { No } \\
\text { Extent }\end{array}$ & Mean & SD \\
\hline & & $\begin{array}{l}\text { Death of close } \\
\text { relative due to STI or } \\
\text { abortion }\end{array}$ & $22(4.4)$ & $53(10.6)$ & $20(85)$ & $405(81.0)$ & 1.4 & 1. \\
\hline & & $\begin{array}{l}\text { Others (counselling } \\
\text { service) }\end{array}$ & $40(8.0)$ & $27(5.4)$ & $28(5.6)$ & $405(41.0)$ & 2.0 & 1. \\
\hline & & $\begin{array}{l}\text { Virtual social } \\
\text { media }\end{array}$ & $330(76)$ & $95(19.0)$ & $25(5.0)$ & $50(10.0)$ & 3.4 & \\
\hline & & $\begin{array}{l}\text { Family planning } \\
\text { advocacy/Clinic }\end{array}$ & \multicolumn{2}{|c|}{$100(20.0) 21(4.2)$} & $109(20.8)$ & $270(54.0)$ & 1.9 & 0. \\
\hline & & $\begin{array}{l}\text { Family } \\
\text { members/Parents, } \\
\text { sisters and brothers }\end{array}$ & $13(2.6)$ & $26(5.2)$ & $200(40.0)$ & $261(52.2)$ & 1.6 & 1. \\
\hline & & $\begin{array}{l}\text { Workshops/Seminar } \\
\text { and meetings }\end{array}$ & $24(4.8)$ & $43(8.6)$ & $103(26.6)$ & $330(66.0)$ & 1.5 & 1. \\
\hline & & $\begin{array}{l}\text { Peer } \quad \text { Group/ } \\
\text { /Classmates }\end{array}$ & $320(64)$ & $53(10.6)$ & $22(4.4)$ & $105(21.0)$ & 3.2 & 0.5 \\
\hline & & $\begin{array}{l}\text { Family Planning } \\
\text { Clinic }\end{array}$ & $57(11.4)$ & $40(8.0)$ & $53(10.6)$ & $350(70.0)$ & 1.4 & 0.5 \\
\hline Weig & d Mean & Library/ & $67(33.4)$ & $48(9.6)$ & $90(18.0)$ & $\begin{array}{l}295(59.0) \\
\mathbf{1 . 9}\end{array}$ & 1.7 & 1. \\
\hline
\end{tabular}

Note: $0.0-1.4=$ No Extent; 1.5- 2.4 = Low Extent; 2.5 - 3.4 = Moderate Extent; 3.5- 4.00 = High Extent

On the extent of reproductive health practices among female undergraduates in private universities in Osun State, table 2 presented the extent of engagement of the female students in sexual activities as moderate $(m e a n=2.7)$ while the extent of pleasure feelings for sexual activities is low (mean=2.4). The take on conditions for pregnancy as sperm (mean=2.8); Uterus (mean=2.3); the extent to which they agreed with ovulation and menstruation having a relationship is also low (mean=2.1). Furthermore, use of contraceptives has a mean of 1.8; both sexes responsible for contraceptives (mean $=2.9)$; contraceptive effectiveness (mean $=2.8$ ) and convenience of buying or using contraceptive (mean=1.9).

On the other hand, some respondents agreed to a low extent that surgical (mean=1.7) is a saver way of dealing with unintended pregnancy; medical abortion (mean=1.5) and preparing to give birth to the child (mean=1.8). All the variables listed for impacting sexual and contraceptive knowledge have means below the weighted mean of 1.9 except for counselling (mean=2.0); Virtual social media (mean=3.4); family planning $($ mean $=1.9)$ and peer group/classmates (mean=3.2).

The weighted mean of the table is given as 1.9 which indicated that reproductive health practices among female undergraduates of private universities in Osun state is low. Despite the moderate extent of awareness of health reproductive information of the female undergraduates, their practices of the reproductive health are at low extent. Meanwhile, only few of the reproductive health are moderately practiced by the students. The result of this study agreed with the earlier work of Otoide, et al (2001) in a study of 149 respondents aged 15-19 in Benin City, Nigeria noted that $86 \%$ prefer abortion, stating that the use of family planning methods is riskier than abortion irrespective of the fact that it is the leading cause of maternal mortality in Nigeria with $80 \%$ of the death occurring among young people. This study also corroborated the work of Adebusonye (1999) in Ibadan, South West of Nigeria noted that among 2,769 and 2,803 in-school young female and male adolescents respectively a high proportion of the subjects had current boy/girlfriends. In same vein.

\section{Conclusion}

The research concludes that the awareness of reproductive health information is of a moderate extent among the female undergraduates. However, the reproductive health practices among female undergraduates of private universities in Osun state are low. The moderate extent of awareness of health reproductive information of the female undergraduates could not translate to a moderate reproductive health practice rather a low extent of reproductive health practice. However, only few of the reproductive health issues are moderately practiced by the undergraduate in the study area.

\section{Recommendation}

i. Although the awareness of reproductive health information is at a moderate extent among the female undergraduates, it is recommended that educators of reproductive health practice should intensify their 
efforts on sources of awareness such as counseling services extent on creating awareness on reproductive health issue of the students.

ii. Since the majority of the respondents attested that they have confidence in information derived from friends and peers, the director of the students' affairs unit of the university college hospital should see that the peer promoters' program is strengthened and extended, since it is a very effective channel for reaching female undergraduates.

\section{References}

Adamchak, S., Katherine B., MacLaren, L, Magnani R, Nelson K, et al. (2000) A guide to monitoring and evaluating adolescent reproductive health programs. Focus on Young Adults, Tool Series 5.

Adebusoye, P. M. (1999) Determinants of Women's Decision-Making Authority in Nigeria: The Ethnic Dimension. Sociological Forum 14, pages399-424

Ajuwon, A. J. (2005) Benefits of Sexuality Education for Young People in Nigeria. African Regional Health Education Centre. Department of Health Promotion and Education College of Medicine University of Ibadan Lagos, Nigeria March 24, 2005

Bloom, P. (2011) Family, Community, Trolley Problems, and the Crisis in Moral Vol. 99 Issue 2 Welly Online Libraryhttps://doi.org/10.1111/j.1467-9736.2011.00701.x

Hall, K.S., Moreau C., Trussell J. (February 2012). "Determinants of and disparities in reproductive health service use among adolescent and young adult women in the United States, 2002-2008". American Journal of Public Health. 102 (2): 359-67. doi:10.2105/ajph.2011.300380. PMC 3483992. PMID 22390451.

Kinsman, J., S. Nyanzi, and R. C. Pool. 2000. Socializing influences and the value of sex: The experience of adolescent school girls in rural Masaka, Uganda. Culture, Health \& Sexuality 2, no. 2: 151-66.

Meekers, D., G. Stallworthy, and J. Harris. 1997. Changing adolescents' beliefs about protective sexual behaviour: The Botswana Tsa Banana Program. Working Paper No. 3. Washington, DC: Population Services International, Research Division.

Mitchell, K., S. Nakamanya, A. Kamali, and J.A.G. +61“1 '1`1'1+9. 2001. Community-based HIV/AIDS education in rural Uganda: Which channel is most effective? Health Education Research 16, no. 4: 411-23.

Muyinda, H., J. Nakuya, R.C. Pool, and J.A.G. Whitworth. (2003). Harnessing the Senga institution of adolescent sex education for the control of HIV and STDs in rural Uganda. AIDS Care 15, no. 2: 159-67.

Maguen S, Armistead LP, Kalichman S. Predictors of HIV antibody testing among gay, lesbian, and bisexual youth. J Adolesc Health 2000; 26:252-257.

Otoide, V.O., Oronsaye, F. and Okonofua, F.E. (2001) Sexual and Contraceptive Use among Secondary Students in Benin City, Nigeria. Journal of Obstetrics Gynaecology, 23, 261-265.

Oyo-Ita, A. E., Kalu, Q. N., Mkpanam, N. E., Etuk, S. J. (2002) Knowledge of reproductive health issues among secondary school adolescents in Calabar, Nigeria. African zzJournal Onlines. Vol. 3 No. 1 (2004). DOI: 10.4314 /gjms.v3i1.10133.

Population Action International (PAI) (2009) Submission related to information on efforts undertaken, including methods used, to assess the costs and benefits of adaptation options, as well as views on lessons learned, good practices, gaps and needs (See FCC/SBSTA/2008/6, paragraph 51).

Ross, D.A., Dick, B. and Ferguson. F. (2006). Preventing HIV/AIDS in young people; A Systematic review of evidence from developing countries. In Technical report series, ed. UNAIDS Interagency Task Team on Young People, 1-357. Geneva: WHO.

Singh, S., A. Bankole, and V. Woog. (2005). Evaluating the need for sex education in developing countries: Sexual behaviour, knowledge of preventing sexually transmitted infections/HIV and unplanned pregnancy. Sex Education 5, no. 4: 307-31.

Straight Talk Foundation. (1998). Communication for better health: Keeping adolescents safe, ed. T. Aguta, 1. Kampala: SIDA, Save the Children Alliance and UNICEF.

Strauss, A., and J. Corbin. (1990). Basics of qualitative research: Grounded theory procedures and techniques. Newbury Park, CA: Sage.

UNAID (2004) Report on the global AIDS epidemic: 4th global report. Geneva, (UNAIDS/04.16E). Report of the Department of Prevention of Diseases on HIV/AIDS. Tehran, Ministry of Health and Medical Education, 2002. Why are adolescents so vulnerable to sexually transmitted infections? Progress in reproductive health research, 2003, No. 64:5

UNESCO. (2018. p. 22) International technical guidance on sexuality education: an evidence- informed approach (PDF). Paris: UNESCO. 2018. p. 22. ISBN 978-92-3-100259-5.

UNESCO PROAP (1998) Regional Clearing House on Population Education and Communication and United Nations Population Fund. Handbook for Educating on Adolescent Reproductive and Sexual Health. Bangkok, 1998

United Nations Statistics Division (2009) Live births by age of mother and sex of child, general and age-specific 
fertility rates: latest available year, 2000-2009 - United Nations Statistics Division - Demographic and Social Statistics

United Nations Population Division. (2018) "Adolescent fertility rate (births per 1,000 women ages 15-19)". Retrieved 16 March 2019.

Vygotsky, Lev S. (1986) Thought and iMnguage. Translated by Alex Kozuiin. Cambridge, MA; MIT Press.

World Health Organization. (2017). "Preventing early pregnancy and poor reproductive outcomes among adolescents in developing countries". World Health Organization. Retrieved September 23, 2017.

Willms, D. G., and N. A. Johnson. (1993a). Essentials in qualitative research: A notebook for the field. Unpublished field notebook for qualitative researcher, Rakai Project, Uganda. Woog, V. (2003). Annotated bibliography on HIV/AIDS and youth in sub-Saharan Africa. Occasional report, 53. New York: The Alan Guttmacher Institute. 